\title{
THE APPLICATION OF GROUP SOCIAL GUIDANCE IN THE DEVELOPMENT OF DRUG CONVICTS IN CORRECTIONAL INSTITUTIONS
}

\author{
Ulang Mangun Sosiawan \\ Badan Penelitian dan Pengembangan Hukum dan Hak Asasi Manusia, \\ Kementerian Hukum dan Hak Asasi Manusia Republik Indonesia, Jakarta \\ Corresponding email: ulangmangun862@gmail.com \\ Paper received on: 17-05-2021; Revised on: 15-08-2021; Approved to be published on: 06-09-2021 \\ DOI: http://dx.doi.org/10.30641/dejure.2021.V21.345-368
}

\begin{abstract}
Group social guidance is a method of social work that aims to help individuals to improve their social functions through certain experiences within the group so that they are able to overcome the problems they face, whether problems involving themselves, their group and society. In providing guidance for drug convicts, group social guidance tends to be more effective than individual social guidance. The forms of group social guidance carried out in correctional institutions include general education, skills education, mental spiritual development, sociocultural and work activities. The problems that were studied are how to apply group social guidance for drug convicts, what the benefits of the guidance are and whether there are obstacles it faces. The method used is empirical normative method. The results of the study concluded that (1) Group social guidance for drug convicts is carried out in collaboration with the Wahana Bhakti Sejahtera Foundation which specifically handles drug convicts and it has been running properly, implemented through spiritual group activities, sports, arts, legal awareness and work guidance. (2) Group social guidance activities show good results, as can be seen from the positive self-changes in drug convicts. (3) The obstacles are the limited infrastructure for development, drug convicts' laziness in following guidance, the lack of application of values and the lack of active participation of the officers as social workers in conducting guidance. It is recommended to add facilities and infrastructure for medical therapy and social rehabilitation for convicts who are ex-drug users.
\end{abstract}

Keywords: group social guidance; development; convicts

\section{INTRODUCTION}

The development of society dynamics has unwittingly created various problems, one of which is drug abuse which is not only detrimental to the users but also has an economic, social and national security impact. This is a threat to the life of the nation and state, so that overcoming it also requires cooperation among countries, nations, and religious communities.

Drug abuse in Indonesia has been classified as an extraordinary crime. Indonesia is not only used as a transit area for illicit drug trafficking, but has also been used as a production area and marketing area for several types of drugs. The target also does not consider gender, both women and men of all ages and backgrounds have the possibility to fall into drug abuse.

The problem of abuse of narcotics, psychotropics and other addictive substances (hereinafter referred to as drugs) is very important considering that drugs have an effect on physical and mental health, and if used in the right dosage and under the supervision of a doctor or psychiatrists, they can be used for medical or research purposes, but if they are misused or used not in accordance with treatment standards, they can be dangerous ${ }^{1}$.

In addition, drug abuse is a very complex problem, both in terms of causes and consequences. The cause is the complexity of various factors, including physical and psychological factors of the perpetrators as well as environmental factors, both micro and macro. The consequences are also very complex and broad, not only for the perpetrators, but also for society, the nation and mankind.

Based on data from the Ministry of Law and Human Rights' Health and Rehabilitation Services in 2020, the number of drug convicts who have carried out Medical and Social Rehabilitation is

1 Hari Sasangka, Narkotika dan Psikotropika Dalam Hukum Pidana (Bandung: CV. Mandar Maju, 2003), 4-5. 
25,614 people consisting of 5,046 people in 2019 and increasing to 20,568 people in $2020^{2}$.

The number of drug abuse cases has resulted in an increase in the number of drug convicts in correctional institutions. The drug convicts include users, dealers, and drug lords. With the increase in the number of convicts/detainees of drug cases mentioned above, correctional institutions must further optimize their duties in developing drug convicts so that they do not repeat their actions as stated in the correctional system which is the guideline for developing correctional inmates.

According to Law Number 12 Year 1995 concerning Corrections ${ }^{3}$, what is meant by the Correctional System is: An order regarding the direction, boundaries and methods of developing correctional inmates based on Pancasila which is carried out in an integrated manner among the mentors, those who are developed, and the community to improve the quality of the correctional inmates so that they are aware of their mistakes, improve themselves, and do not repeat crimes so that they can be accepted again by the community, can play an active role in development, and can live naturally as good and responsible citizens.

This means that through correctional institutions, the correctional system which is the final series of the legal process carries out heavy duties and responsibilities. On the other hand, correctional institutions have 10 (ten) Correctional Principles which must always be used as guidelines in carrying out their duties, so that the development process can run in a directed and orderly manner in accordance with applicable regulations. The 10 (ten) Correctional Principles contained in the book from correctional center to correctional center are as follows ${ }^{4}$ :

1. Protecting and providing life provisions so that they can carry out their roles as good and useful citizens;

2. The imposition of a punishment is not an act of revenge by the state;

\footnotetext{
Direktorat Jenderal Pemasyarakatan, Refleksi Akhir Tahun 2020 (Jakarta, 2020), 38.

3 Undang-Undang Republik Indonesia, UndangUndang RI No. 12 Tahun 1995 tentang Pemasyarakatan, 1995.

4 M Djakaria, Penulisan Tentang Penerapan Sistem Pemasyarakatan (Jakarta, 1987), 33-34.
}

3. Providing guidance (not torture) so that they repent;

4. The state has no right to make them worse or more malicious than before they were sentenced;

5. During the loss of freedom of movement, convicts/correctional students must be introduced and should not be exiled from the community;

6. The work given to convicts and correctional students should not be just a time filler;

7. Guidance and education provided for convicts and correctional students must be based on Pancasila;

8. Guidance and correctional students as lost people are human, and they must be treated as human beings;

9. Convicts and correctional students are only sentenced to loss of independence as the only suffering they can experience;

10. Providing and developing facilities that can support rehabilitative, corrective, and educative functions in the Correctional System.

Efforts to treat the violators are by restoring the cracked life and livelihood, so that law violators can re-integrate in a healthy manner with the community. This is in line with the opinion of Bahrudin Suryobroto, that correction is not only the purpose of imprisonment, but as a process aimed at restoring the unity of the relationship of life and livelihood, which is established between the convict individual and the community in order to become a "whole human being" towards a just and prosperous society based on Pancasila. ${ }^{5}$

Based on the brief description above, the correctional institution as one of the Technical Implementing Units is required to always carry out development for convicts in accordance with the development program and always pay attention to the development of convicts' behavior while they are in correctional institution without compromising their protection. Drug convicts, whether users, dealers and drug lords, have tendency of different behavior compared to other convicts. It is caused by the influence

\footnotetext{
5 Baharudin Suryobroto, "Pelaksanaan Sistem Pemasyarakatan," Majalah Lembaga Pembina Hukum Nasional No. 16 Tahun V (Jakarta, 2021), 1-2.
} 
of the substances contained in drugs. Therefore, correctional institutions provide special development for drug convicts compared to other convicts. Drug addicts and victims of drug abuse are required to undergo medical rehabilitation or social rehabilitation at a drug dependence rehabilitation center. It is intended to recover and/ or develop physical, mental and social abilities of addicts from drug dependence.

In treating drug convicts, a discipline approach is needed, one of which is a social approach through social guidance, but what the researcher focused on in this study is the method of social guidance applied to convicts in the form of groups, which is called group social guidance. Drug convicts who live in correctional institutions are basically a form of group that interacts and influences each other. This is based on the definition of group proposed by Lewin, that the core of a group is the relationship between groups that are reciprocal and influence each other. In a group, a group member has a special bond within the group where the bond does not include all convicts, but only a small group that has different elements and motivations with the same goal.

Therefore, to carry out development related to groups, the method of group social guidance (social group work) is a development pattern that tends to be more efficient to apply. In addition to the large number of convicts, limited officers and time are the reasons for implementing group social guidance which, when compared to individual social guidance, certainly requires more time and energy because it must be done individually for each convict.

When observed in the field, there are problems that often occur in correctional institutions, one of which is Over Capacity. Almost all correctional institutions in Indonesia experience Over Capacity, which can have an impact on the poor health condition and psychological atmosphere of the correctional inmates. As a result, it is easy for conflicts to occur among correctional inmates, and the development is not optimal and does not run according to regulations. At its peak, there are riots and cases of correctional inmates escaping due to inadequate supervision as a result of the imbalance in the number of prison guards/ correctional officers and correctional inmates.

The facts and reality in the field encouraged the researcher to discuss the application of group social guidance which is specifically carried out in Correctional Institutions, so that it can be applied optimally later. In correctional institutions, the form of development for drug convicts is certainly different from the form of development for convicts of other cases. The development for drug convicts requires professional staff to handle them. For this reason, it is necessary to apply knowledge and skills about social work by correctional officers in the context of developing drug convicts, especially the method of group social guidance.

Based on the description above, it is necessary to conduct research related to the application of social guidance in group development for drug convicts in correctional institutions. The problems that will be the focus of this research are how the application of group social guidance for drug convicts in correctional institutions is and what the benefits and obstacles in implementing group social guidance are. The purpose of this research is to find out the things that are the problems in this research. Theoretically, the function of this research is to support the establishment and development of policies and recommendations. Practically, this research can be used as input for stakeholders including the government, academicians, practitioners and the community.

\section{RESEARCH METHOD}

The method used in this research is empirical normative method by combining library research with field research. Therefore, this research used both secondary data and primary data. The secondary data is in the form of library materials, namely laws and regulations, including Law No. 12 Year 1995 Concerning Corrections and Law No. 35 Year 2009 concerning Narcotics ${ }^{6}$ as well as books relevant to the research. The primary data sample in this research was taken from the entire analysis group/unit in the form of the phenomenon of group development carried out in Correctional Institutions. The sample was taken from the data of group development involving Correctional Institutions officers, BNN (the National Narcotics Board), and correctional inmates.

\footnotetext{
6 Undang-Undang Republik Indonesia, UndangUndang RI No. 35 tahun 2009 Tentang Narkotika, n.d.
} 


\section{DISCUSSION}

\section{A. The General Description of Drugs}

\section{The Definition of Drugs (Narkoba)}

Narkoba (drugs) is an abbreviation of narcotics and dangerous drugs/substances. In addition to "narkoba" another term introduced in particular by the Ministry of Health of the Republic of Indonesia is Napza, which is an abbreviation of Narcotics, Psychotropics and Addictive Substances. These terms, either "narkoba" or "napza", refer to a group of compounds that generally have a risk of addiction for its users.

According to health experts, drugs are actually psychotropic compounds that are commonly used to anesthetize patients when they are about to undergo surgery or drugs for certain diseases. But now this perception is misinterpreted due to the usage outside the intended use and dosage.

NAPZA (Narcotics, Alcohol, Psychotropics and addictive substances) have a more complete meaning, where the drugs that are considered dangerous are narcotics, alcohol, psychotropics and addictive substances. Because psychotropics and narcotics are classified as drugs or substances that are harmful to health, the production, distribution, supply, delivery, exports and imports of these drugs are regulated in law. Provisions regulating narcotics and psychotropics are contained in Law Number 5 Year 1997 concerning Psychotropics and Law Number 22 Year 1997 concerning Narcotics, which was later amended into Law number 35 Year 2009.

According to Law Number 35 Year 2009 concerning Narcotics, narcotics are substances or drugs derived from plants or non-plants, both synthetic and semi-synthetic, which can cause a decrease or change in consciousness, loss of taste, reduce or eliminate pain, and can cause dependence. In relation to high or low dependence, narcotics are classified into 3 categories, namely class I narcotics, class II narcotics, and class III narcotics.

a. Class I narcotics are narcotics that can be used for scientific development purposes and are not used in therapy, and have a very high potential to cause dependence. Class I narcotics include: Papaver Somniferum L, raw opium, cooked opium, coca plant, coca leaf, raw cocaine, cocaine, and cannabis plant. There are 26 types in total.

b. Class II narcotics are narcotics that have the power to cause moderate dependence, can be used as a last resort for medical and scientific purposes, for example: Morphine, Fentanyl, Ecgonine, and Pethidine. There are 87 types in total.

c. Class III narcotics are narcotics that have the power to cause low dependence and are widely used in medicine and for scientific development purposes, such as: Codeine and Ethyl morphine.

\section{The Effects of Drugs}

In the book Deteksi dan Intervensi Dini Korban Penyalahgunaan Narkoba (Early Detection and Intervention of Drug Abuse Victims $)^{7}$, it is stated that broadly speaking, drugs can be classified into three main groups according to the effects they cause, namely:

a. Stimulants (improves emotions, behavior and ways of thinking).

These stimulant drugs can result in increased activity in the central nervous system and can accelerate mental processes and can make a person more alert and excited. Examples: caffeine, nicotine, amphetamines and cocaine.

b. Depressants (suppress emotions, behavior and ways of thinking).

Depressant drugs can reduce activity in the central nervous system and can make the user more relaxed and less aware of their surroundings. For example: analgesics (antipain medicine), alcohol, benzodiazepines, and narcotics such as heroin, morphine, and methadone.

c. Hallucinogens (causing hallucinations)

Hallucinogenic drugs can change perceptions and views of time and place and can make the user hear or see something that is not actually there or see or hear according to different perceptions. Drugs in this group are LSD (Lysergic Acid), marijuana, various types of mushrooms (cow dung mushrooms) and various types of plants such as mescaline, peyote, and marijuana.

\footnotetext{
Badan Narkotika Nasional, Deteksi dan Intervensi Dini Korban Penyalahgunaan Narkoba (Jakarta, 2003), 6-8.
} 


\section{Factors Causing Drug Abuse}

According to Graham Blaine, a psychiatrist, the causes of drug abuse are:

a. To prove courage in performing dangerous and risky actions, such as speeding, fighting or associating with women.

b. To challenge an authority from parents, teachers, law, or other competent institutions.

c. To facilitate sexual acts

d. To escape from loneliness and want to gain emotional experience

e. To try to find the meaning of life

f. To fill the void and fill the feeling of boredom due to lack of activity.

g. To get rid of the frustration and anxiety caused by problems that cannot be overcome by a dead-end way of thinking, especially for those who have a personality that is not harmonious

h. To follow the will of friends and to foster solidarity with friends, and

i. Because it is driven by a sense of curiosity and because of fun (just for kid).

\section{The Effects of Drug Abuse}

According to the Drug Abuse model ${ }^{8}$, for drug abusers, drug abuse results in the following:

a. From physical aspect, drug abuse can cause disturbances in the functioning of the brain, liver, kidneys, heart, lungs, intestines, as well as disorders of general health conditions;

b. Psychologically, drug abuse can cause disturbances in mental and personality functions, including emotional, intellectual, perceptual functions, and self-control;

c. Drug abuse can cause a very high economic burden, to buy drugs, cause termination of employment, or if the users are still in school, it causes a decrease in morale and learning achievement, to drop out of school, which means destroying their future.

d. For those who are married, it can lead to the destruction of family life.

e. The occurrence of unlawful acts with the threat of severe punishment up to the death penalty.

\footnotetext{
8 Budi Sulaksana, Penyalahgunaan Narkoba (Jakarta: Akademi Ilmu Pemasyarakatan, 2003), 21-23.
}

f. Drug abuse through sharing drug needles among drug addicts carries the threat of contracting HIV/AIDS, which leads to prolonged suffering and vain death.

\section{B. The General Description of Correctional Institution}

\section{The Definition of Correctional Institution}

According to Law No. 12 Year 1995, Correctional Institution is a place to carry out the development of Convicts and Correctional Students. Therefore, what is meant by correctional institution is an organization/body or platform to accommodate development activities for convicts, both physically and spiritually, in order to return to normal life in society.

Correctional institutions have 2 (two) functions, namely: First, correctional institutions as educational institutions, meaning a place to develop, educate, and guide convicts so that they have the quality of piety to God Almighty, national and state awareness, intelligence, positive attitudes and behavior, law awareness, Pancasila personality, moral integrity, and are aware of their mistakes so as to be able to re-integrate with healthy physical and spiritual condition in society after serving their punishment period. Second, the Correctional Institutions as a development institution that aims to prepare correctional inmates to have the abilities, skills, and expertise according to their talents and interests that can be used as initial capital for those concerned to return to life in society in a good and responsible manner'.

\section{Types and Classification of Correctional Institutions}

Types of Correctional Institutions are divided by taking into account the age and gender of the convicts.

(1) General Correctional Institutions, to accommodate adult male convicts who are more than 25 years old.

(2) Special Correctional Institutions

a. Women's correctional institutions to accommodate adult female convicts who are more than 21 years old or married.

\footnotetext{
9 Adi Sujatno, Pencerahan Di Balik Penjara, dari Sangkar menjadi Sanggaruntuk menjadi Manusia Mandiri (Jakarta: Teraju, 2008), 136-137.
} 
b. Youth correctional institutions to accommodate youth convicts aged 1825 years.

c. Children correctional institutions consist of Correctional Institution for Boys and Correctional Institution for Girls.

Classification of correctional institutions based on capacity, location and work activities.

a. Class I Correctional Institution, located in the Provincial Capital with a capacity of more than 500 people.

b. Class IIA Correctional Institution, located in Municipality/District with a capacity of 250 to 500 people.

c. Class IIB Correctional Institution, located at the district level, with a capacity of less than 250 people.

There 300 Technical Executive Work Units of Correction in Correctional Institutions, consisting of 13 work units of Class I Correctional Institutions, 71 work units of Class IIA Correctional Institutions, 100 work units of Class IIB Correctional Institutions, 17 work units of Class III Correctional Institutions, 22 work units of Narcotics Correctional Institutions, 7 work units of Open Correctional Institutions, 33 work units of Women's Correctional Institutions, 4 work units of Youth Correctional Institutions s, 2 work units of Children Correctional Institutions, and 33 work units of Children Development Institutions ${ }^{10}$.

The number of Correctional Institution Officers throughout Indonesia is 10,605 people consisting of 9,090 male human resources and 1,515 female human resources. Based on the Structural and Functional Classification, the Correctional Institutions officers consist of 6,263 security personnel, 1,212 supervisors, 1,212 structural members and 1,818 technical support work units ${ }^{11}$.

1o Sri Utami, Tantangan Penanganan Penyalahguna/ Pecandu Narkoba di Indonesia (Jakarta, 2018), 2-3.

" Direktorat Jenderal Pemasyarakatan, "Sistem Database Pemasyarakatan," di akses Agustus 2021, last modified 2021, http://smslap.ditjenpas.go.id/public/sdm/ current/monthly/kanwil.

\section{Social Workers}

1. Definition

Article 1 Paragraph 4 of Law Number 11 of 2009 concerning Social Welfare states that a professional social worker is someone who works, both in government and private institutions, who have the competence and profession of social work, and care in social work obtained through education, training, and/or practical experience of social work to carry out service tasks and handling social problems. While Walter Friedlander ${ }^{12}$ suggests that social workers are professional services based on knowledge and skills in human relations which aim to help individuals, groups, and communities to improve their standard and quality of life in order to achieve a happier level of life.

In their efforts to provide social services, social workers are required to adhere to the basic views in accordance with the theoretical module of social work practice (Made P. Suandhe: 2-4), namely: (a) the belief that every individual has dignity and self-respect; (b) belief that individuals have the right to determine and fulfill their needs; (c) the belief that every individual has the same opportunities which are limited only by their abilities; and (4) social workers must avoid prejudice and discrimination against the clients they serve.

The purpose of social work is to help people to be able to help themselves. The essence of the goals of social work can be described as follows: (a) improving human abilities in dealing with life's tasks in society, solving problems they face on a daily basis, and realizing values; (b) connecting people with systems that provide sources of services and opportunities to achieve their life goals; (c) improving the quality and quantity of existing resources in an effective, efficient and humane manner; and (d) making a positive contribution to social change, the realization of improvement and development of policies and laws in the field of social welfare.

Group social guidance is a method in social work that is carried out by utilizing the role of groups to help individual members to overcome the social problems they face. The definition of group

\footnotetext{
12 Walter Friedlander, Pengantar Kesejahteraan Sosial (Jakarta: Gema Insani Press, 1961), 1-3.
} 
social guidance according to Made Suandhe ${ }^{13}$ is explained as follows: Group social guidance (social group work) is a method of social work that aims to help individuals (group members) to improve their social functions through certain experiences in the group so that they are able to overcome problems they face, whether problems involving themselves, their groups and society.

In carrying out their duties, a social worker has a role, namely: (1) Information provider, namely a person who has the ability to convey information needed by a client (2) Motivator, namely a person who has the ability to have other people in such a way that other people want to do something in accordance with his wishes to encourage or support (3) Mediator, namely a person who acts as an intermediary, liaison, mediator, peacemaker for the disputing parties (4) Facilitator, namely a person who allows the client to get facilities that are difficult for him to obtain (5) Catalysts, namely social workers as a place to complain, share about problems (6) Therapists, namely people in charge of solving problems faced by clients in various ways, either directly or indirectly (7) Advocate, namely a person who helps clients in fighting for their interests, their rights, their opportunities which are hindered/impeded (8) Educator, namely a person who acts as a teacher, instructor, educator for a particular subject.

\section{In the book Intervensi Psikososial ${ }^{14}$} (Psychosocial Interventions), it is stated that there are 4 (four) types of groups, namely as follows:

a. Self-help group, which is structured small group that interacts voluntarily to help each other to share experiences and information in order to achieve agreed goals. This group tends to have similarities in terms of age, problems and others.

b. Healing group (therapeutic group): This group uses group interaction as a means of healing social-emotional problems experienced by clients/group members, so that the leadership of this group requires a person who has the ability, perception and knowledge of human nature and group dynamics, the ability in group counseling

13 Made Suandhe, Metode dan Praktek Pekerjaan Sosial (Jakarta: Akademi Ilmu Pemasyarakatan, 2004), 11-13.

14 Departemen Sosial, Intervensi Psikologi (Jakarta, 2001), 164. and the ability to use groups in the behavior change process.

c. Socialization group: The purpose of this group is to develop or change the behavior and attitudes of group members in order to form attitudes that are accepted by their social environment. The activities of this group are in the form of forming and developing social skills, increasing self-confidence and developing life for the future.

d. Recreation group: This group aims to provide fun activities; the activities are in the form of light exercises and often spontaneous.

\section{Group Social Guidance (Social Group Work)}

In general, group social guidance is defined as a method of inter-person assistance developed from the Social Work professional environment that uses small groups as a tool or framework to achieve individual or group goals ${ }^{15}$. In this definition, the key words social group work can only be done in a group which usually has the same characteristics of the problem. Meanwhile, Made P. Siandhe explains that social group work is a method of Social Work to help individuals to improve their social functions through regular group experiences so that the individuals are able to effectively overcome the problems surrounding themselves, their groups and the community ${ }^{16}$.

Based on this definition, it appears that the impact of social group work is quite broad, not limited to one individual only. The concept of social group work in the practice of Social Work can be used for activities that are educative, rehabilitative, therapeutic, promotive, preventive, developmental and recreational. Therefore, the social group work method can be said to be very appropriate in developing convicts, because convicts themselves are an example of a group consisting of people who have problems of violating the law.

The group atmosphere and dynamics are strongly influenced by the form of leadership in

15 Soetarso, Metode-Metode penyembuhan Sosial dalam Praktek Pekerjaan Sosial (Bandung: Sekolah Tinggi Kesejahteraan Sosial, 1979), 69-71.

16 Made Suandhe, Kapita Selekta Teori Praktek Pekerjaan Sosial (Jakarta: Departemen Sosial R.I Pusat Pendidikan dan Pelatihan Tenaga Kerja Sosial, 1988), 11-12. 
the group, membership formation, rules, and the division of duties and authority within the group. The concept to help people to help themselves is manifested in the ability of officers to develop the ability to adapt themselves well to other members in the group, to their own group and to the community. The ability developed is in the form of open exchange of opinions where decisions are then taken by all group members through deliberation. Social group work also uses various techniques in approaching group members.

\section{Community Social Guidance (Community Organization)}

Made P. Suandhe provides definition that community social guidance is an effort to maintain balance more effectively and progressively among the existing resources in the community and the needs of the community's welfare. This balance can be achieved through the assistance of professional workers and the participation of groups in society. This effort takes the form of a process that includes the presentation of various problems and needs, determination of problem solving and the basis for preparing an activity plan).

Associated with convicts' needs, in overcoming the need for social welfare, they always demand that the fulfillment of these needs can be obtained from various sources of social welfare that exist in society, be it natural, human, or non-material sources. Community social guidance aims to maintain continuity between social welfare needs and existing resources. However, this effort requires a relatively long time, therefore it is necessary to prepare beforehand the following things:

a. Fact finding, factual data searching and concrete development and activities.

b. Program development, namely the direction and development of social welfare service programs.

c. Standards, namely improving and increasing the standards of social welfare.

d. Coordination, namely opening the widest possibility for interaction among groups, organizations, and individuals seen in social welfare efforts.

e. Education, namely through education and training in developing the community's ability to absorb various programs,

\section{f. Application of Therapeutic Community} Method

Therapeutic Community is a method of social rehabilitation aimed at victims of drug abuse, who are considered as a family and consist of people who have the same problem. The main concept of a therapeutic community is to help themselves and others, so that changes in behavior are expected from negative to positive behavior ${ }^{17}$.

In carrying out the Therapeutic community method, it is not enough just to apply written and unwritten philosophy, but there are still other components called the 4 structures, which are the desired changes from the method:

a. Changes in behavior (behavior modification)

The formation of positive behavior is through the way residents learn existing techniques by using the tools of the house correctly.

b. Control of psychological and emotional aspects

Changes in the perception of selfunderstanding, self-development and emotional control exercises through static groups, peer reprimand when emotional and other related work.

c. Development of intellectual and spiritual aspects

Changes in mindset and development of intellectual and spiritual aspects by giving residents a group discussion forum about education on the dangers of drugs by means of recreation and the application of religious values.

d. Improvement of work skills and life and survival skills (Vocational and Survival).

The development of a learning concept in a social environment based on self-skills, where a resident will be assessed and adjusted to his or her role so as to facilitate the process of being accepted again by the community.

4. The Social Work Approach Methods are as follows:

a. Method of Individual Social Guidance (Social Case Work). One of the methods used by social workers in helping their clients

\footnotetext{
${ }_{17}$ Komunitas Terapeutik, Daiam Rehabilitasi Sosl dan Penyaiahgunaan Narkoba, Metode Therapeutic Community (Jakarta: Badan Narkotika Nasional, 2004), 3-4.
} 
is individual social guidance which has a definition as a method of social work used by social workers to help individuals with social problems through an individual approach.

b. Method of Group Social Guidance (social group work). Group social guidance is a method in social work that is carried out by utilizing the role of groups to help individual members in order to overcome the social problems they face. Then it is assumed that group social guidance can only be applied in group activities that are recreational. However, modern social work concept has emphasized that group social guidance method can be used for educational, rehabilitative, therapeutic, promotive, preventive, and developmental activities.

c. Community Social Guidance Method, namely the process of creating and maintaining a more effective balance between community resources and the need for welfare ${ }^{18}$.

\section{Techniques in Group Social Guidance Method}

Some of the techniques that can be applied in the group social guidance method are as follows:

a. Group discussion technique (group discussion): This technique can encourage the willingness and ability of each group member to express their opinions verbally.

b. Role playing technique: In this technique, each group member is trained to be able to play a role (speak and carry out tasks) according to the role he or she plays.

c. The technique of competing in public (Games): In this technique, each group member is trained to be able to cooperate with his or her members and to accept the victory or defeat of the group.

d. Camping technique. This technique educates group members to be able to live independently with existing potential or resources, and help each other in completing a task at one camp.

\footnotetext{
18 Hariwoerjanto Kasmi, Metodologi dan Praktek Pekerjaan Sosial Metode Bimbingan Sosial Kelompok (Bandung: Pusat Pendidikan dan Pelatihan Pegawai Departemen Sosial R.I., 1987), 17.
}

\section{Correctional Process}

Based on the Decree of the Minister of Justice of the Republic of Indonesia Number M.02-PK.04.10 Year 1990 concerning Patterns of Development for Convicts/Detainees, it can be stated that the development of adult convicts is carried out through four stages, including the following:

\section{Correctional Process}

\section{a. First Stage}

At this stage, every convict who enters a correctional institution is examined to find out everything about himself, including the reasons he committed an offense, and all information about himself that can be obtained from his family, former employer or superior, co-workers, the victim of his actions, as well as from other institution officers who have handled his case.

This stage of development is called the initial stage of development, which is an activity of observing, researching, and introducing the environment to determine the planning for the implementation of the personality and independence development program. This stage begins when the person concerned is declared as convict until 1/3 (one-third) of his sentence period. Guidance at this stage is still carried out by the correctional institution and its supervision is carried out maximally.

b. Second Stage

If the development process for the convict in question has lasted for a third of the actual sentence period, and in the opinion of the Correctional Observer Team (TPP) enough progress has been made, such as by showing conviction, improvement, discipline, and compliance with the applicable code of conduct in the correctional institution, the convict in question shall be given more freedom and shall be placed in correctional institution with medium security supervision.

c. Third Stage

If the development process for the convict has lasted for $1 / 2$ (half) of the actual sentence period, and according to the TPP enough progress has been made, both physically and mentally, as well as 
in terms of skills, then the forum for the development process shall be expanded with assimilation, the implementation of which begins after the end of the second stage until $2 / 3$ of the sentence period. At this stage, the development is still carried out within the correctional institution and its supervision has entered the assimilation stage and the convict can then be given parole or prerelease discharge with minimum security supervision.

\section{d. Fourth Stage}

If the development process has lasted for $2 / 3$ of the actual sentence period or at least 9 (nine) months. This development is called the final stage of development, which is an activity in the form of planning and implementing an integration program that starts from the end of the advanced stage until the end of the sentence period of the convict in question. For the development at this stage, the convicts who meet the requirements are given pre-release discharge or parole and the development is carried out outside the correctional institution by the Corrections Bureau.

\section{Forms of Development}

Every convict is obliged to follow all the development programs given to him. The Decree of the Minister of Justice of the Republic of Indonesia Number: M.02-PK.04.10 Year $1990^{19}$ states that the forms of development for convicts are as follows: (1) general education, namely eradicating three illiteracy (illiteracy, number illiteracy and language illiteracy) through providing Package A Learning Group which carried out by convicts with tutors from correctional institution officers and technically the convicts receive guidance and supervision from the Public Education office of the Ministry of Education and Culture. (2) Skills education includes weaving, pipe engineering, carving, mechanic, sewing, radio repair, aquaculture and industry and so on. (3) Spiritual mental development, including religious and character education. (4) Socio-cultural development includes family visits, learning

\footnotetext{
19 Keputusan Menteri Republik Indonesia, Keputusan Menteri Kehakiman Republik Indonesia Nomor M.o2PK.04.10 Tahun 1990 tentang Pola Pembinaan Narapidana/Tahanan. (Indonesia, 1990).
}

painting, karawitan (musical arts), dance, music, singing and other arts. (5) Recreational activities are activities directed at cultivating physical and spiritual fitness through sports, fun entertainment, reading books and newspapers/magazines ${ }^{20}$.

\section{Social Therapy and Rehabilitation}

The Decree of the Director General of Corrections Number E.55.PK.04.10 Year 2005 concerning Strategies for Overcoming HIV/AIDS in Drug Abuse in Correctional Institutions and State Detention Centers in Indonesia ${ }^{21}$ states that narcotics and psychotropic users must be given therapy and rehabilitation. Based on the foregoing, convicts in correctional institutions are entitled to rehabilitation as an effort to develop drug convicts. In the Guidebook for Implementation of Integrated Therapy and Rehabilitation in Correctional Institutions and State Detention Centers ${ }^{22}$, it is stated that there are various social therapy and rehabilitation techniques that have been known to be applied to correctional inmates/State Detention Centers' inmates, namely:

(1) CBT (Cognitive behavior therapy), which is a therapy activity that uses book guidelines on basic knowledge about HIV/AIDS and sexually transmitted diseases (STDs).

(2) Narcotic Anonymous is a continuation of the CBT program which is a series of regular meetings of drug addicts and abusers to share experiences, strengths and hopes with the principle of helping each other to stay clean and free from drugs and alcohol.

(3) Peer Educator is an activity that begins with the provision of knowledge about drugs, STIs (sexually transmitted infections), HIV/ AIDS and other associated diseases.

(4) VCT (Voluntary Counseling and Testing) is a form of activity that uses medical therapy and social rehabilitation methods.

\footnotetext{
${ }^{20}$ Noor Farikhah, "Penerapan Bimbingan Sosial Kelompok dalam Pembinaan Narapidana Kasus Narkoba" (Akademi Ilmu Pemasyarakatan, 2008), 1718.

${ }^{21}$ Direktorat Jenderal Pemasyarakatan, "Strategi Penanggulangan HIV/AIDS dan Penyalahgunaan Narkoba Pada lembaga Pemasyarakatan Dan Rumah Tahanan Negara di Indonesia" (2005).

22 Badan Narkotika Nasional, Panduan Pelaksanaan Terapi dan Rehabilitasi Terpadu di Lembaga Pemasyarakatan dan Rumah Tahanan. (Jakarta, 2005), 12-13.
} 
(5) Criminon is a therapy that aims to form a convict/detainee so that he does not repeat his crime again.

(6) Therapeutic Community (TC) is a method of social rehabilitation aimed at victims of drug abuse, which is a family consisting of people who have the same problem and have the same goal, namely helping themselves and others.

(7) Religious therapy and rehabilitation are social rehabilitation through religion as one of the rehabilitation methods carried out in several pesantren (Islamic boarding schools) in Indonesia.

\section{ANALYSIS}

The development for drug convicts cannot be equated with non-drug convicts because they have different backgrounds, therefore a permanent procedure for the treatment of high-risk convicts is issued, including the treatment of narcotic convicts ${ }^{23}$.

The placement of convicts in Correctional Institutions is only differentiated between drug cases and criminal cases. Whereas in drug case, it should be distinguished again according to the case, whether as users, dealers, or drug lords because users, dealers, and drug lords require different development. Drug convicts who are users require more medical and mental healing, while for dealers it must pay more attention to the security aspect in order to break the chain of drug trafficking.

Like other correctional institutions, the Nusa Kambangan Class IIA Correctional Institution also applies group social guidance in developing their convicts, while still being guided by 10 (ten) principles of correction. The development at the Nusa Kambangan Class IIA Correctional Institution always goes well. However, it must be acknowledged that with the existing limitations, of course, in the implementation in the field there are gaps with what should be. This is a task that must be completed immediately, both by all officers of the Nusa Kambangan Class IIA Correctional Institution and by the Directorate General of Corrections.

${ }_{23}$ [PP], Peraturan Pemerintah No.31 Tahun 1999 Tentang Pembinaan dan Pembimbingan Warga Binaan Pemasyarakatan (Indonesia, 1999).
The implementation of group social guidance in correctional institutions is carried out in collaboration with government institutions and non-government institutions. This refers to Article $9^{24}$ which states as follows: In the context of implementing the development and guidance of correctional convicts, the minister may cooperate with relevant government institutions, other community institutions or individuals whose activities are in line with the implementation of the correctional system as referred to in Article 2 and Article $3^{25}$.

On a daily basis, this guidance is carried out with the guidance from parties outside correctional institutions. Although basically the involvement of officers plays an important role, the limited circumstances create a disconnection between officers and convicts from the approach of group social guidance. When viewed from a scientific point of view, this group social guidance method has various elements and components in its application, for example, there are requirements to be a good facilitator, a code of ethics in guiding groups, social workers' views on clients, approach methods in group social guidance and other things related to group social guidance.

But in reality, those things rarely get attention and it seems that group guidance is implemented minimally. However, there are still some officers who hold the principles as social workers and always apply them correctly. The existence of such conditions will have an unfavorable impact. In addition to the less optimal results achieved in the development, this will also diminish the knowledge that has been obtained by a social worker because it tends not to be utilized. In the end, the researcher concludes that although in the Correctional Institutions there are officers who have the provision of social worker education, this has not been utilized maximally.

In principle, a group goal can be achieved by structured and planned group activities and the group is guided by professional social workers. This is what makes the group does not move alone without control. In carrying out the development for drug convicts, the Class IIA Nusa Kambangan Correctional Institutions divided two groups of social guidance, namely group social guidance

24 Indonesia, Undang-Undang RI No. 12 Tahun 1995 tentang Pemasyarakatan.

25 Ibid. 
for drug convicts and guidance for this group has different benefits and obstacles with the same goal.

\section{A. Group Social Guidance for Drug Convicts}

Based on the Decree of the Director General of Corrections Number E.55.PK.04.10 Year 2005 concerning Strategies for Overcoming HIV/AIDS and Drug Abuse in Correctional Institutions and State Detention Centers in Indonesia, narcotics and psychotropic users must be given therapy and rehabilitation.

Social rehabilitation is carried out at Correctional Institutions in collaboration with the Wahana Bhakti Sejahtera Foundation. This collaboration has been implemented since 2006 which is specifically aimed at drug convicts with Harm Reduction, which is a harm reduction program, the most important of which is the spread of HIV/AIDS and Hepatitis.

The general objective is that the correctional inmates can easily obtain information about the adverse effects of drug abuse and the prevention of HIV/AIDS transmission. Meanwhile, the specific objectives are as follows: (1) to prevent or reduce the risk of HIV/AIDS transmission among the correctional inmates; (2) to provide support (peer support groups) for victims of drug abuse, especially those who are positively infected with HIV/AIDS; (3) to refer for basic health services (clinic, hospital doctor); and (4) to facilitate VCT services.

The benefits that can be felt by drug convicts from the program provided by the Wahana Bhakti Sejahtera Foundation are as follows: (1) increasing self-confidence (2) getting to know more the effects of drugs (3) a change in attitude to being open and willing to share experiences among members as a way to get rid of drug addiction. (4) being cheerful and willing to get along, and (5) good relationship with family.

The implementation of group guidance carried out by the Wahana Bhakti Sejahtera Foundation did not run optimally because there were several obstacles including: (1) lack of knowledge of officers regarding drug abuse, especially regarding the forms, types and effects arising from drug abuse and how to carry out development and guidance for drug convicts; (2) the place of implementation is not adequate; (3) the activities are monotonous; and (4) there is laziness among the convicts due to boredom in participating in the guidance program.

The efforts made by Correctional Institutions in overcoming the problems mentioned above are: (1) In order to overcome the problem of officers' ignorance about drugs, Correctional Institutions cooperate with the Wahana Bhakti Sejahtera Foundation to conduct training for staff in order to provide information about the dangers of drugs and the training has been implemented.

(2) To overcome the boredom of convicts in participating in the Wahana Bhakti Sejahtera Foundation program, Correctional Institutions accept cooperation with Wahana Bhakti Sejahtera Foundation and it is possible for other NGOs to cooperate continuously.

\section{B. Group Social Guidance That Mixes with Non-Drug Convicts}

\section{The Development}

The purpose of development is consciousness. To gain consciousness within one's self, one must know oneself. One will be able to change himself to be better, more advanced, more positive. Without knowing oneself, it is too difficult and even impossible for one to change oneself. How is something going to change if one does not know exactly what it is?

Regarding consciousness as the goal of developing convicts, the method of achieving it is carried out through various stages, namely;

(1) Knowing oneself: Convicts are brought in an atmosphere and situation that can reflect, explore and know oneself; knowing the most basic thing within oneself, looking for answers to questions "where do I come from', 'why do I exist' and 'where will I go after I'm gone'.

(2) Having religious awareness: Awareness of belief in God Almighty; aware of being God's creatures, as individuals who have limitations and as humans who are able to determine their own future. Able to realize this awareness in actions as religious beings.

(3) Knowing self-potential: Convicts are invited to be able to recognize their own potential, to be able to develop positive things and develop positive values, broaden the perspective; always trying to advance, increase knowledge and experience to move 
forward and strive to advance and develop human potential.

(4) Knowing how to motivate: Always trying to develop a positive way of thinking, behaving and developing a personality to become more mature

(5) Able to motivate others: Convicts who have known themselves, have been able to motivate themselves, are expected to be able to motivate other convicts, their groups, their families and the surrounding community.

(6) Able to have a high awareness whether for oneself, family, group, surrounding community.

(7) Able to think and act: Convicts are expected to be able to think positively, to be able to make decisions for themselves and to be able to act based on their own decisions.

(8) Have strong self-confidence: Convicts who have known themselves are expected to have strong self-confidence, to believe in God, and to believe that they are able to change their behavior, actions and condition to be better.

(9) Having responsibility: If the convict has been able to think, make decisions and act, then the convict must also be able to be responsible for his decisions and actions.

(10) Becoming a complete person: At the last stage, it is hoped that the convict will become a human being with a complete personality; Able to face all challenges, obstacles, and any problems in his every step and life; Be a consistent human being, having personality, responsible, forward-oriented, always want to move forward with a positive way of thinking.

\section{Spiritual Group Activities}

Drug convicts usually lack of religious awareness so that the process of socializing or interacting with the community is easily influenced by the state of the social environment. The influence that is absorbed is a negative influence so that when using drugs, a new awareness is created that satisfies themselves as a place of escape. Therefore, a religious approach needs to be given so that it is hoped that it will increase the convicts' faith and they are not easily tempted to use drugs again.
This spiritual group activity is one of the most effective means of development because it has benefits for convicts such as: (a) there is assimilation into the Correctional Institution; (b) increasing knowledge about religion; (c) becoming diligent in worship; (d) improving morals and character; (e) there is feeling of remorse that arises within the convict for what he has done in the past; (f) increasing discipline; and (g) socializing with fellow convicts.

In the implementation of the spiritual group activities, the researcher did not find any significant obstacles, but the absence of officers/social workers who played a role in this activity became a problem that resulted in a lack of supervision. Although this activity has been going well, the presence of a guiding officer will certainly bring another atmosphere for convicts, especially in optimizing the results of development.

(a) Islam: So far, the activities carried out by correctional institutions have been running well and continuously so that they have a positive impact on drug convicts. From the results of the researcher's interview with one of the drug convicts who turned out to be a mosque head, the researcher deemed that the mosque head has a good understanding of religion and what is even more interesting is the mosque head's statement which states that he has received a valuable lesson in a correctional institution.

(b) Christianity: In Christian religious activities, the researcher did not find any significant obstacles and the activities run as scheduled. All Christian convicts and detainees were always present to participate in these activities solemnly.

\section{Sports Group Activities}

The sports group activities carried out by the correctional institutions consist of volleyball, table tennis, and Physical Fitness Gymnastics (SKJ). Through sports activities, it is hoped that in addition to a healthy body, sportsmanship, discipline, and responsibility are also embedded; developing self-confidence, a spirit of unity, and developing a sense of mutual understanding. Exercise can also reduce convicts' dependence on narcotics both physically and psychologically. In addition, exercise can reduce sadness and can use free time. This sports group is a type of funoriented recreational group. 
(a) Volleyball: the volleyball activity showed that the appreciation of the convicts was very good, even though the temperature was hot but the spirit in practicing was extraordinary so that the coaches were happy to give the material. And so far, a reliable volleyball team has been established. Usually, on Fridays the team has a training match with the officers and the convicts always win. So that this volleyball activity can improve the relation and sense of unity among convicts and officers, eliminate feelings of restraint and pressure and instill a sense of discipline and responsibility.

(b) Table Tennis: The implementation of this activity did not run as scheduled because there was no supervision from the officers. In addition, it was due to the limited facilities and infrastructure so that until the time the researcher conducted this research, there were no convicts who were seeded in table tennis game.

(c) Physical fitness gymnastics: This activity is from convicts and for convicts. It means that the gymnastics trainer is from the convicts themselves who do have special talents in the field of gymnastics. This activity has several obstacles, namely there is no direct involvement of officers, lack of collection of cassettes, and inadequate audio player.

\section{Art Group Activities}

The art group activities in the correctional institution are taught to convicts who do have special interests and talents in these fields. While the benefits obtained from these activities are: (a) there is assimilation into the correctional institution; (b) is used to welcome every official guest in the correctional institution; (c) to cultivate body and soul towards a healthier life; (d) to develop self-confidence and cohesiveness towards fellow group members; (e) to channel their interests and talents into the arts (f) to fill spare time; and (g) as entertainment and socialization media among convicts so that they can communicate with each other and exchange opinions, so that other convicts can influence drug convicts so they do not abuse drugs again.

(1) Dance art: The implementation of this activity run according to a predetermined schedule and sometimes adds hours of practice if it is necessary. For every performance, not all convicts who are trained can perform but they must go through a selection of who can perform because the performance adapts to the existing equipment. The obstacles are the lack of facilities provided, the sound system which is no longer suitable for use, and other equipment which is inadequate.

(2) Music art: In the implementation, the convicts often come early and they are even willing to wait for their mentor to come. This shows that in this development they are very enthusiastic and useful, especially for drug convicts. In the implementation of these activities, the researcher did not find any significant obstacles, but as previously explained, there were no officers/social workers who played a role in these activities.

\section{Moral Activities}

In the implementation, the mentors convey any problems related to the material and discuss actual problems about the condition of convicts in the last week, then discuss and find solutions so that these activities can train convicts in solving problems, develop their courage in expressing opinions in public, socialize with other convicts, and train to accept the opinions of others. However, in its implementation there are also obstacles including the officers having difficulty in evaluating and supervising the implementation of these activities.

\section{Work Guidance Group Activities}

The workshops in the Correctional Institution are used as a means of education and training, where the work activities of the correctional inmates are not just a time filler, but are oriented towards developing the talents and abilities of the correctional inmates which will eventually be able to support their lives in the community later after serving their sentence period.

Apart from being a means of education and training, the provision of work skills can also function as a means of development where the convicts carry out productive activities that are indirectly used to support national development. In the implementation, these activities are guided directly by officers in the field of work activities and sometimes guided by convicts who are already proficient in their fields. In the implementation, the workshop activities encountered obstacles such as: (a) the limited place of work activities; 
(b) the marketing of the products of work skills is still largely limited to meeting the needs among the correctional institution officers; (c) there is no permanent cooperative relationship with external parties in terms of marketing; and (d) the lack of tools and materials so that some convicts are still unemployed.

In the implementation of guidance for drug convicts who mingle with criminal convicts, it turns out that there are several obstacles. The efforts made by the Correctional Institution are (a) making a shift schedule for the development staff, where one staff is tasked every day to act as supervisor and facilitator of activities carried out in the afternoon. The shift starts at 11.0016.00 WIB (Western Indonesian Time Zone); (b) providing skills training in collaboration with related parties, and usually the training is temporary with a relatively short period of time in the context of batik training; (c) welcoming visits from outside the correctional institution as a form of assimilation into the correctional institution, and (d) repairing the building and maintain the cleanliness and beauty of the correctional institution environment.

Convicts who are in the Correctional Institution in the Medium Security category receive independence and personality development. As for what can determine the success of the correctional system, it depends on the material subjects that support each other, these subjects are:

(1) Convicts.

Convicts must be given guidance, mental education and skills that cannot be separated from and together with elements in society so that they can carry out their social functions again. In this case, it is hoped that there will be participation from convicts who are active and positive as participants in the development program.

(2) Correctional Officers.

Correctional officers as motors, mentors and coaches, should be equipped with mature and professional knowledge, so that they know the direction of the development, whose goal is to realize how important their duties are, and love their duties or in other words have high dedication and discipline.

(3) The community.

The community should always participate fully and provide support in assisting the implementation of development for convicts. The community must accept and not stigmatize ex-convicts, let alone threat and always suspect ex-convicts. Convicts are a product of community. Therefore, regarding correctional inmates in improving their lives, the community must participate in the development of convicts.

\section{Revitalizing the Application of Group Social Guidance for Drug Convicts in Correctional Institutions}

The implementation of revitalization sees that correctional institution as the spearhead of the implementation of the principle of protection is a place to achieve the goals of development through education, rehabilitation and integration. Correctional institution is a place of development for criminals. The function of the correctional institution as an institution must be able to increase added value for groups of drug convicts and groups who mingle with non-drug convicts by sharpening the convict development program.

The principles of organizing drug convict development include:

a) Placement of convicts is based on the results of community research that shows an assessment of the level of risk of the convicts. Convicts who are placed are not in the highrisk category who have shown changes in behavior and decreased levels of risk so that they are transferred to maximum security.

b) The security and supervision systems are designed maximally, where all forms of activity and behavior of convicts are closely observed and monitored to avoid disturbances to security and order.

c) The placement of convicts in the block is carried out according to the categories: gender, type of crime, length of sentence period, age, and/or other categories according to the needs of development.

d) Convicts' activities in rooms and blocks, according to a certain schedule by officers.

e) Interaction and communication among fellow convicts as well as with officers are allowed under supervision.

f) Convicts are given access to get visiting services in the visiting room through direct face-to-face with visitors, but are separated 
by glass partitions so that convicts and visitors cannot come into direct contact.

g) Implementation of development activities is carried out in rooms for development activities that have been prepared by officers.

The implementation of the personality development program is closely related to efforts to restore life relations and the lives of convicts, where the implementation of the development of drug convicts seeks to provide guidance for convicts so that behavior changes occur with indicators of success namely convicts can realize the mistakes that have been made, understand the rights and responsibilities that must be carried out, understand all forms of regulations that must be obeyed and have the discipline to follow all forms of development organized by the correctional institution.

The convict development program is carried out in three stages, namely:

1) Early-stage development

a. Admission and Orientation are used as a means that can help convicts to get used to living in the correctional institution environment, so that they can socialize properly. Admission and orientation provide guidance for convicts in order that they can understand the life order that must be followed while in the correctional institution. In addition, this period is also used as a means for officers to find out the personality or behavior of convicts so that they can know the conditions of convicts and the development treatment that will be carried out. At this stage, the planning of a training program for convicts is also carried out in accordance with the results of observations during the admission and orientation of convicts. The planning of the development program is stated in the development contract.

b. Mental Spiritual Development. Mental spiritual development is an activity aimed at improving and increasing the faith and piety of convicts. It is hoped that changes in the behavior of the convicts' character will be realized, namely realizing mistakes and understanding the consequences of the actions that have been committed. The activities are carried out in the form of religious lectures and the implementation of mandatory worship activities in accordance with the religious beliefs of each convict.

Indicators of the success of the implementation of the development program in the early stage are the changes in the behavior of convicts, such as the emergence of self-awareness of mistakes and actions committed and the willingness of the convicts to change in a more positive direction. At this early stage, an evaluation and assessment of the implementation of the early stage of the development program are also carried out through a session of the Correctional Observer Team at the correctional institution. For convicts who have shown changes in behavior in accordance with the results of the evaluation, they will continue to follow the development program at the first advanced stage.

2) First Advanced Stage of Development

a. Legal Awareness Development. Since convicts commit crimes, they are considered not aware of the applicable law or regulations, so when they are placed in correctional institutions, it is hoped that the convicts will be able to realize the applicable law or at least obey the applicable regulations. The development of legal awareness is oriented towards the goal to require the values of knowledge and understanding of convicts regarding legal provisions

b. Conflict Management Training. It is a development activity that aims to improve the ability of convicts to manage conflicts that occur constructively, communicate effectively, increase selfconfidence, and manage emotions. Therefore, it is hoped that convicts will be able to change the orientation of conflict handling from a destructive approach into a more constructive approach.

An indicator of the success of the implementation of the first advanced stage of the development program is changes in 
convicts' behavior; the emergence of selfcompliance with all forms of mandated rules and code of conduct in correctional institutions. In addition, the convicts have the ability to overcome various problems within themselves. For convicts who have shown changes in behavior in accordance with the results of the evaluation, they will continue to follow the development program in the second advanced stage.

3) Second Advanced Stage of Development

a. Development of Intellectual Ability. The Development of intellectual ability is carried out through the implementation of formal education and informal education which is held according to the needs and abilities through courses. The development of intellectual ability is carried out in order to increase the knowledge and thinking ability of the convicts to support positive activities during the development period.

b. Development of National and State Awareness. The implementation of the national and state awareness development program is carried out to increase knowledge of Pancasila and increase a sense of nationalism with the aim of making the convicts realize that the actions that they have committed have a negative impact on the state. The achievement of the objectives of the implementation of this development is carried out by correctional officers by providing an understanding of the love for the homeland and efforts to increase the sense of the spirit of nationalism.

At the end of the development stage, the development of changes in the behavior of the convicts will be evaluated through a session mechanism by the Correctional Observer Team which determines the evaluation and assessment of changes in the convicts' behavior. Those who have shown changes in behavior with indicators of showing changes in the level of awareness, compliance and self-discipline will be transferred to the medium security correctional institutions.

\section{Implementation of the Independence Program}

The implementation of the independence program for convicts in correctional institutions includes: (1) basic level education and skills training; (2) advanced level education and skills training and (3) proficient level education and skills training. Every convict who has attended education and skills training is given a certificate of skill and expertise to be used later after being released.

This independence development activity for convicts aims to, firstly, be able to provide encouragement to convicts, so that they have a strong spirit/motivation to live a better life by exploring the existing potential that can be useful and beneficial for themselves and others in living life after being released. Second, to prepare correctional inmates to become citizens who are responsible and obey the law and applicable regulation so they can live better life again after coming back to the society.

After observing the implementation of education and skills training, the result of the observation is the Readiness of Correctional Institutions.

\section{E. Strategies in Optimizing the Revitalization of Convict Development}

The revitalization of implementation of corrections is an effort to optimize the implementation of corrections as a form of treatment for detainees, convicts and clients as well as protection of rights of ownership of evidence. The revitalization program at Correctional Institutions is carried out through strengthening the correctional institutions by implementing the classification of correctional institutions into functions that are graded as (1) Super Maximum Security Correctional Institutions (2) Maximum Security Correctional Institutions (3) Medium Security Correctional Institutions, and (4) Minimum Security Correctional Institutions. The strategy in optimizing the revitalization of convict development can be explained as follows:

\section{a. The Aspect of Context}

1) The needs that need to be met in the revitalization program for Convict Development are those related to the implementation of convict development 
in all classifications of correctional institution including strengthening of:

a) Assessment of risks and needs through coordination of assessors, PKs and correctional institution officers.

b) Placement of convicts is based on the revitalization classification by conducting institutional assessments in all UPT (Technical Service Unit) in Indonesia based on the characteristics of occupancy/ convicts and the readiness of officers to carry out placement assessment.

c) Preparation of development programs and methods of development for each classification of revitalization so that there is a mutual understanding of the program considering that revitalization prioritizes a combination of individual and communal development

d) Assessment of Development through standardization of guidelines and assessment instruments so that they can be implemented in an integrated manner at UPT including Personality Assessment, Skills Assessment, Mental Condition and Attitude Assessment.

e) The transfer is based on the revitalization classification which emphasizes the synchronization of special requirements for high-risk convicts (Narcotics) so that they are not concentrated in mediumclass correctional institutions by establishing a work activity program in Medium Correctional Institutions or increasing the security level to medium in Minimum Correctional Institutions specifically for work units that employ narcotics convicts.

2) Development of goals that need to be achieved in the Convict Development program is carried out through: a) Optimizing the implementation of intervention programs for convicts in stages with an accountable assessment and taking valid measurements related to the achievement of the goals of revitalization.

b) It is necessary to harmonize various regulations governing the rights of convicts with the Regulation of the Minister of Law and Human Rights Number 35 Year 2018, so that there are no overlapped regulations.

3) Institutional development in the aspect of revitalization of convict development

a) strengthening organizational aspects through strengthening institutional structures in Correctional Institutions that focus on carrying out the duties and functions of developing convicts through a single-purpose, dual-purpose or multi-purpose approach.

b) There is a need for a grand design and roadmap for the Correctional Revitalization policy, which contains the determination of targets that must be met.

c) Shared perception/understanding of the policy goals, especially the Regulation of the Minister of Law and Human Rights Number 35 Year 2018. The essence of the Regulation of the Minister of Law and Human Rights is to improve correctional management so that it is more effective, efficient, workload does not accumulate, and achievements can be achieved.

\section{b. The Aspect of Input}

1) Preparation of activity plans or programs related to revitalization contained in work documents that are disseminated and implemented include:

a) An organizational assessment plan that ensures the type of classification with occupancy characteristics is related to the 
shape of the UPT building and the possibility of combining Single, Double or Multi-Purpose models.

b) Preparation of program plans and development activities for each classification of correctional institutions using the right method, either with an individual or communal approach.

c) Organizing a Technical Meeting to discuss work planning at a UPT that has been prepared based on a revitalization program to be decided and disseminated at the local, regional and national levels.

2) The ability of Human Resources to carry out the revitalization program for Convict Development in Super Maximum Correctional Institutions, Maximum Correctional Institutions, Medium Correctional Institutions and Minimum Correctional Institutions

a) Workload assessment, to determine the allocation of fulfillment of the number of officers in Correctional Institutions who are tasked with carrying out the Convict Development at Super Maximum, Maximum, Medium and Minimum Correctional Institutions.

b) Improving the quality of officers through the fulfillment of qualifications, competence and integrity through education and training on an ongoing basis concerning the Personality Development Program, Independence Development, Skills and Expertise Education taught as well as the field of management in the field of production and services.

3) Availability of Facility and Infrastructure to support Convict Development in all classifications of Correctional Institution includes strengthening:

a) Preparation of facility and infrastructure standards in the form of zoning for single-purpose, double-purpose and multi-purpose
UPT Correctional Institution buildings and plans to gradually fulfill them.

b) Maximum fulfillment of facility and infrastructure in the context of direct support for the implementation of development activities on the classification of Super Maximum, Maximum, Medium and Minimum and plans to gradually fulfill them.

4) Availability of Budget to support Convict Development activities:

a) Budget allocation for the purpose of fulfilling facility and infrastructure based on revitalization in Super Maximum, Maximum, Medium and Minimum Correctional Institutions.

b) Budget allocation for the purpose of implementing development activities and all methods in Super Maximum, Maximum, Medium and Minimum Correctional Institution by calculating the form of operation whether single, dual or multi-purpose.

c) Preparing alternative budgeting support through partnership cooperation which is mapped based on the scope of regional, national or international cooperation specifically to support service activities of rights fulfillment.

5) The need for improvement of the Organization and Work Procedures at Correctional Institutions.

6) Establishing Correctional Institutions with various classifications in adjacent areas, so as to facilitate the transfer of convicts and be integrated in the process, for example: in one former residency (Cirebon, Indramayu, Majalengka and Kuningan) it is designated as Super Maximum Security, Maximum Security, Medium Security and Minimum Security Correctional Institutions.

\section{c. The Aspect of Process}

1) Convicts' reaction to the revitalizationbased development model 
a) It is necessary to measure the response of convicts through a survey of convicts' satisfaction in the treatment for convicts in each classification of correctional institutions.

b) It is necessary to measure the response of convicts through a satisfaction survey related to the development program that is adjusted to the revitalizationbased classification.

2) It is necessary to measure the impact of the revitalization program on the development of convicts

a) Measurement of the development of convicts is related to the implementation of personality development program according to the classification.

b) Measurement of the development of convicts based on the Development of Independ ence is related to the implementation of the program according to the classification.

c) Measurement of the development of convicts based on mental health development is related to the implementation of the program according to the classification.

d) Measurement of the development of convicts' attitudes based on the implementation of the program according to the classification.

3) The Revitalization Program for Convict Development and Its Influence on the Achievement of Goals of Corrections

a) The preparation of indicators of the success of the development program is related to the concept of being a whole person.

b) The preparation of indicators of the success of the development program is related to the concept of realizing mistakes.

c) The preparation of indicators of the success of the development program is related to the concept of being a whole person. d) The preparation of indicators of the success of the personality service program is related to the concept of self-improvement.

e) The preparation of indicators of the success of the development program is related to the concept of not repeating crimes.

f) The preparation of indicators of the success of the development program is related to the concept of re-acceptance by the community.

g) The preparation of indicators of the success of the development program is related to the concept of being able to play an active role in development.

h) The preparation of indicators of the success of the development program is related to the concept of living naturally as a good and responsible citizen.

For correctional institutions that have implemented a policy of revitalizing correctional institution administration, the transfer of convicts from Super Maximum Security Correctional Institutions to Maximum Security Correctional Institutions has gone well, and from Maximum Security Correctional Institutions to Medium Security Correctional Institutions has gone well too. However, the problem when transferring prisoners from Medium Security Correctional Institutions to Minimum Security Correctional Institutions is that convicts from Medium Security Correctional Institutions cannot be transferred to Minimum Security Correctional Institutions because of regulatory constraints, where the Narcotics Law affects the implementation of development in correctional institutions. The Corrections Law also still sees the development from the crimes, not based on the results of the assessment (change in behavior). In the end, the pattern of development will stop at Medium Security Correctional Institutions, considering that in general, correctional inmates throughout Indonesia are exposed to drug cases. Therefore, it is necessary to harmonize the regulations governing corrections, so that 
there are no more policies that are stopped due to unsupportive regulations.

\section{F. Problems or Obstacles encountered}

The internal problems faced by officers in conducting development for groups of drug convicts and groups who mingle with non-drug convicts in the Correctional Institution are: ${ }^{26}$

1. The limited number of correctional officers which is not proportional to the number of existing convicts. In addition, there is also a lack of uniform equipment such as special clothes for the emergency response team, and other equipment that supports security and order.

2. The need for additional tools to detect cell phones, which so far are mostly used as a medium for drug transactions that require strict security and supervision in correctional institutions.

3. Conducting a record test of drug use by the internal supervisory team at the correctional institution. The method is through a hair examination. This method is considered effective because it can detect drug use in the last 3 months.

4. In terms of quality, so far there are correctional officers who have never received education and training in order to improve competence which aims to improve the performance of officers.

5. The limited fulfillment of human resource needs in the medical field. There is a lack of doctors, nurses and kitchen staff. In terms of the quality of human resources, basic competencies, qualifications, SDP (IT), assessors and psychology must also be considered.

6. The addition of CCTV is very necessary to increase security and order in correctional institutions.

The obstacles and problems encountered by most correctional institutions in Indonesia regarding facility and infrastructure are ${ }^{27}$ :

\footnotetext{
26 Yulianto, Implementasi Permenkumham Nomor 35 Tahun 2018 tentang Revitalisasi Penyelenggaraan Pemasyarakatan (Jakarta: Balitbangkumham Press, 2021), 49-50.

27 Ibid., 53-54.
}

1. The condition of the correctional institution building is not yet adequate to support the development process as expected, where most of the correctional institution buildings are colonial heritage, with infrastructure conditions that seem haunted and harsh. The high walls that surround the buildings with iron trellises add to the spooky impression of the convicts.

2. Facilities and infrastructure for developing convicts to obtain skills education in correctional institutions are very limited, both in number and in type, and there are even facilities that are no longer functioning, so that they will reduce the output of production carried out by the correctional institutions.

3. Classification of correctional institutions according to the level of risk and needs that are oriented to behavior change and reducing the level of risk of convicts.

4. Alignment of regulations that stipulate that convict with drug cases cannot be placed in open correctional institutions, so that this results in a shortage of convicts, because convicts who are in Medium Security and Maximum Security Correctional Institutions are mostly drug convicts.

5. Limited activities in the independence development program in correctional institutions which include the production of industrial-scale goods or services, as mandated in Article 23 paragraph (2) of the Regulation of the Minister of Law and Human Rights Number 35 Year 2018 concerning the Revitalization of the Correctional System.

6. Normative obstacles are also encountered, where the Narcotics Law affects the implementation of development in correctional institutions. The Corrections Law also still sees development based on the crimes, not based on the results of the assessment. In the end, the pattern of development will stop at correctional institutions, considering that in general correctional inmates throughout Indonesia are exposed to drug cases. 


\section{CONCLUSION}

In principle, the legal regulation regarding the guidance and development of drug convicts in Correctional Institutions is effective enough to meet the needs of the correctional inmates, namely: (a) the process of raising awareness and treatment of violators of the law in special correctional institutions, within the period specified in accordance with the applicable laws and regulations. (b) the placement of convicts is harmonized and carried out by considering their respective religions and human rights, (c) affirmation of the effectiveness of development and guidance of drug convicts based on: (1) convicts' awareness of the consequences of their actions that caused them to become correctional inmates. (2) the convicts admit that they realize their guilt and will not repeat their actions which can send them back to the Correctional Institution. (3) the convicts understand their rights and obligations as correctional inmates.

The procedure and implementation of group social guidance for drug convicts in Correctional Institutions refer to Article 9 of Law No. 12 Year 1995 as referred to in Article 2 and Article 3 through; (a) cooperation with the Wahana Bhakti Sejahtera Foundation which specifically handles drug convicts and it has been running properly. However, in reality, efforts need to be made continuously to find the best solution in overcoming the classic problems that make group social guidance activities in correctional institutions work well (b) Group social guidance for group that mingles with other convicts through group activities of spirituality, sports, arts, character and work guidance whose implementation blends with other convicts.

Group social guidance activities for drug convicts showed good results as seen from the positive self-changes in drug convicts such as discipline, growing sense of responsibility, openness, cheerfulness, self-motivation, selfconfidence, the spirit of obedience, sportsmanship, mutual understanding, the existence of good relations with family and increased religious devotion to God Almighty and regret of their actions, and by associating with other convicts they can communicate with each other and exchange opinions, so that other convicts can influence drug convicts not to abuse drugs anymore. There is also assimilation into Correctional Institution.
Problems or obstacles that exist in the implementation of group social guidance are the limited means of development, the laziness of the convicts in participating in group guidance, the lack of active participation of officers as social workers in providing guidance for drug convicts and there is no permanent cooperative relationship with outsiders in terms of marketing the products of the correctional inmates.

\section{SUGGESTION}

The Head of Correctional Institution should empower their officers as far as possible to be directly involved in group social guidance efforts, especially those who have social work knowledge, and education and training on drugs should be held continuously. If this is not possible, it is necessary to consider the recruitment of officers.

The emphasis of empowering officers in the development program at Correctional Institutions is on the implementation of the development program and personality which is closely related to efforts to restore life relationships and the lives of convicts. The implementation of development of convicts in correctional institutions seeks to provide guidance for convicts so that behavior changes occur with indicators of success such as the convicts can realize the mistakes they have made, understand the rights and responsibilities that must be carried out, understand all forms of regulations that must be obeyed and have the discipline to follow all forms of development organized by the Correctional Institutions.

In addition, in the development it is necessary to pay attention to aspect of scientific guidelines and education and training on drugs should be held continuously, especially regarding the materials, types and effects caused by drugs as well as the development process in overcoming drug cases so that the development and guidance programs can run as expected. If this is not possible, it is necessary to consider the recruitment of officers.

It is necessary to improve the types of social rehabilitation activities, especially regarding the evaluation of each activity that has been carried out, as an effort to obtain the development results that are in accordance with the desired target. In addition, it is necessary to add facilities and infrastructure for medical therapy and social rehabilitation for drug convicts, such as the addition of medical devices, and expansion of 
buildings, by submitting a budget application to the Directorate General of Corrections to fulfill these facilities and infrastructure.

\section{ACKNOWLEDGMENT}

The researcher would like to express gratitude to the Editors, Reviewers, Peer Reviewers and the Journal Management Team of the Research and Development Board for Law and Human Rights, because with their suggestions, corrections and contributions, this paper can be prepared properly and correctly. The researcher would also express his deepest gratitude to the Chief Editor of the De Jure Legal Research Journal who has been pleased to publish this paper.

\section{BIBLIOGRAPHY}

[PP]. Peraturan Pemerintah No.31 Tahun 1999 Tentang Pembinaan dan Pembimbingan Warga Binaan Pemasyarakatan. Indonesia, 1999.

Badan Narkotika Nasional. Deteksi dan Intervensi Dini Korban Penyalahgunaan Narkoba. Jakarta, 2003.

-. Panduan Pelaksanaan Terapi dan Rehabilitasi Terpadu di Lembaga Pemasyarakatan dan Rumah Tahanan. Jakarta, 2005.

Direktorat Jenderal Pemasyarakatan. Refleksi Akhir Tahun 2020. Jakarta, 2020.

—. "Strategi Penanggulangan HIV/AIDS dan Penyalahgunaan Narkoba Pada lembaga Pemasyarakatan Dan Rumah Tahanan Negara di Indonesia" (2005).

Djakaria, M. Penulisan Tentang Penerapan Sistem Pemasyarakatan. Jakarta, 1987.

Farikhah, Noor. "Penerapan Bimbingan Sosial Kelompok dalam Pembinaan Narapidana Kasus Narkoba." Akademi Ilmu Pemasyarakatan, 2008.

Friedlander, Walter. Pengantar Kesejahteraan Sosial. Jakarta: Gema Insani Press, 1961.

Indonesia, Keputusan Menteri Republik. Keputusan Menteri Kehakiman Republik Indonesia Nomor M.02-PK.04.10 Tahun 1990 tentang Pola Pembinaan Narapidanal Tahanan. Indonesia, 1990.
Indonesia, Undang-Undang Republik. UndangUndang RI No. 12 Tahun 1995 tentang Pemasyarakatan, 1995.

- Undang-Undang RI No. 35 tahun 2009 Tentang Narkotika, n.d.

Kasmi, Hariwoerjanto. Metodologi dan Praktek Pekerjaan Sosial Metode Bimbingan Sosial Kelompok. Bandung: Pusat Pendidikan dan Pelatihan Pegawai Departemen Sosial R.I., 1987.

Pemasyarakatan, Direktorat Jenderal. "Sistem Database Pemasyarakatan." di akses Agustus 2021. Last modified 2021. http://smslap. ditjenpas.go.id/public/sdm/current/monthly/ kanwil.

Sasangka, Hari. Narkotika dan Psikotropika Dalam Hukum Pidana. Bandung: CV. Mandar Maju, 2003.

Soetarso. Metode-Metode penyembuhan Sosial dalam Praktek Pekerjaan Sosial. Bandung: Sekolah Tinggi Kesejahteraan Sosial, 1979.

Sosial, Departemen. Intervensi Psikologi. Jakarta, 2001.

Suandhe, Made. Kapita Selekta Teori Praktek Pekerjaan Sosial. Jakarta: Departemen Sosial R.I Pusat Pendidikan dan Pelatihan Tenaga Kerja Sosial, 1988.

- Metode dan Praktek Pekerjaan Sosial. Jakarta: Akademi Ilmu Pemasyarakatan, 2004.

Sujatno, Adi. Pencerahan Di Balik Penjara, dari Sangkar menjadi Sanggaruntuk menjadi Manusia Mandiri. Jakarta: Teraju, 2008.

Sulaksana, Budi. Penyalahgunaan Narkoba. Jakarta: Akademi Ilmu Pemasyarakatan, 2003.

Suryobroto, Baharudin. "Pelaksanaan Sistem Pemasyarakatan." Majalah Lembaga Pembina Hukum Nasional No. 16 Tahun V. Jakarta, 2021.

Terapeutik, Komunitas, Daiam Rehabilitasi Sosl, dan Penyaiahgunaan Narkoba. Metode Therapeutic Community. Jakarta: Badan Narkotika Nasional, 2004.

Utami, Sri. Tantangan Penanganan Penyalahguna/ Pecandu Narkoba di Indonesia. Jakarta, 2018. 
Yulianto. Implementasi Permenkumham Nomor 35 Tahun 2018 tentang Revitalisasi Penyelenggaraan Pemasyarakatan. Jakarta: Balitbangkumham Press, 2021. 